\title{
A comparison of historical and current forest cover in selected areas of the Great Lakes-St. Lawrence Forest of central Ontario
}

\author{
by Paul Leadbitter ${ }^{1}$, David Euler ${ }^{2}$ and Brian Naylor ${ }^{3}$
}

Crown survey notes from the late 1800 s were used to reconstruct forest cover at that time in four forest management units in central Ontario, Canada. Historic forest cover was then compared to forest cover in 1990 based on Forest Resources Inventory (FRI) maps. Regional results indicate that the proportions of maple (Acer spp.) in the forest increased by $12.5 \%$, while balsam fir (Abies balsamea) declined by $3.5 \%$, hemlock (Tsuga canadensis) by $2.3 \%$ and other conifers (larch (Larix laricina) and cedar (Thuja occidentalis)) by 2.1\%. The frequency of occurrence of maple, ash (Fraxinus spp.), yellow birch (Betula alleghaniensis), poplar (Populus spp.) and spruce (Picea spp.) also increased while white birch (Betula papyrifera), hemlock and other hardwoods (e.g., oak (Quercus spp.), basswood (Tilia americana), beech (Fagus grandifolia), elm (Ulmus spp.), ironwood (Ostrya virginiana) and black cherry (Prunus serotina Ehrh.)) declined. The region-wide proportional increase in maple is likely due to timber harvest techniques such as selective logging, effective fire suppression and the ecology of the maple species. Crown survey notes have been a useful tool in reconstructing presettlement forest cover. Survey notes can easily be obtained and used by forest managers and planners to understand presettlement conditions of this forest. Managers can achieve zero net loss of forest types in relation to the presettlement condition by using appropriate silvicultural practices to reduce the proportion of maple.

Key words: Crown Survey records, presettlement forest, Great Lakes-St. Lawrence Forest, working group, frequency of occurrence

Les relevés d'arpentage des terres publiques de la fin des années 1800 ont été utilisés pour reconstituer le couvert forestier de l'époque dans quatre unités d'aménagement forestier du centre de l'Ontario au Canada. Le couvert forestier de cette époque a été comparé par la suite au couvert forestier de 1990 en fonction des cartes de l'Inventaire des ressources forestières. Les résultats régionaux indiquent que la proportion d'érable (Acer spp.) dans les forêts a augmenté de 12,5\% tandis que le sapin baumier (Abies balsamea) a diminué de $3,5 \%$, la pruche (Tsuga canadensis) de $2,3 \%$ et les autres conifères (le mélèze (Larix laricina) et le thuya (Thuja occidentalis)) de 2,1\%. La fréquence de la présence de l'érable, du frêne (Fraxinus spp.), du bouleau jaune (Betula alleghaniensis), du peuplier (Populus spp.) et de l'épinette (Picea spp.) a également augmenté tandis que le bouleau blanc (Betula papyrifera), la pruche et les autres bois francs (par ex., le chêne (Quercus spp.), le tilleul (Tilia americana), le hêtre (Fagus grandifolia), l'orme (Ulmus spp.), l'ostryer (Ostrya virginiana) et le cerisier tardif (Prunus serotina Ehrh.)) ont décliné. L'accroissement proportionnel dans toute la région pour l'érable est vraisemblablement dû aux techniques de récolte telle la coupe sélective, à la suppression totale des feux de forêt et à l'écologie des érables. Les relevés d'arpentage des terres publiques ont été un outil utile pour reconstituer le couvert forestier antérieur à la colonisation. Les relevés d'arpentage peuvent être obtenus facilement et utilisés par les aménagistes forestiers et par les planificateurs pour visualiser les conditions antérieures à la colonisation de ces forêts. Les aménagistes peuvent atteindre une perte nette nulle au niveau des types forestiers en relation avec les conditions antérieures à la colonisation en utilisant les pratiques sylvicoles appropriées pour réduire la proportion d'érable.

Mots-clés : relevés d'arpentage des terres publiques, forêts pré-coloniales, forêt des Grands-Lacs et du St-Laurent, ensemble de peuplements, fréquence de la présence

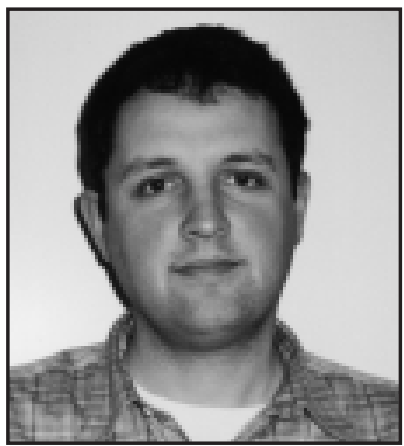

Paul Leadbitter

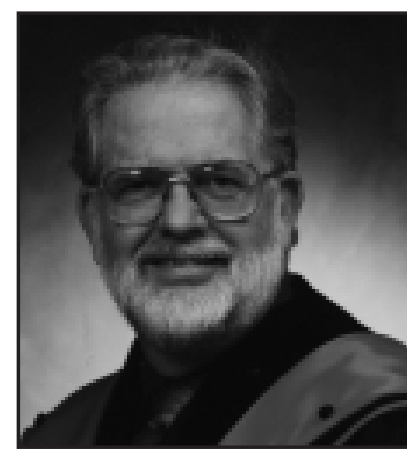

David Euler

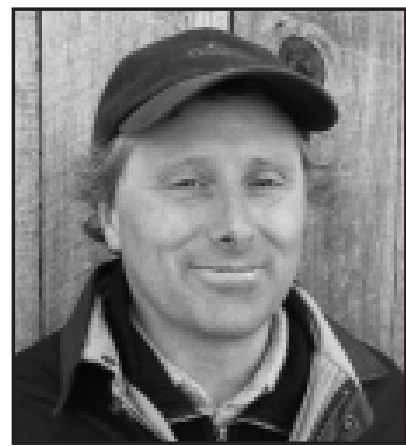

Brian Naylor

\section{Introduction}

In Ontario, surveyors were employed, beginning in the middle of the $19^{\text {th }}$ century, to establish township lines and other legal boundaries as part of the settlement process. The notes and records these surveyors made from about 1860 to 1920 give detailed, qualitative and quantitative descriptions of the forest at that time. In this paper these survey notes have been used to estimate forest cover conditions prior to widespread European settlement. We then compare these historic estimates to information from current forest inventories to determine the apparent change that occurred in the composition of the forest cover within selected management units in the Great Lakes-St. Lawrence Forest of central Ontario over a hundred year period. The results of 


\section{Map Of Ontario Showing The Four Management Units}

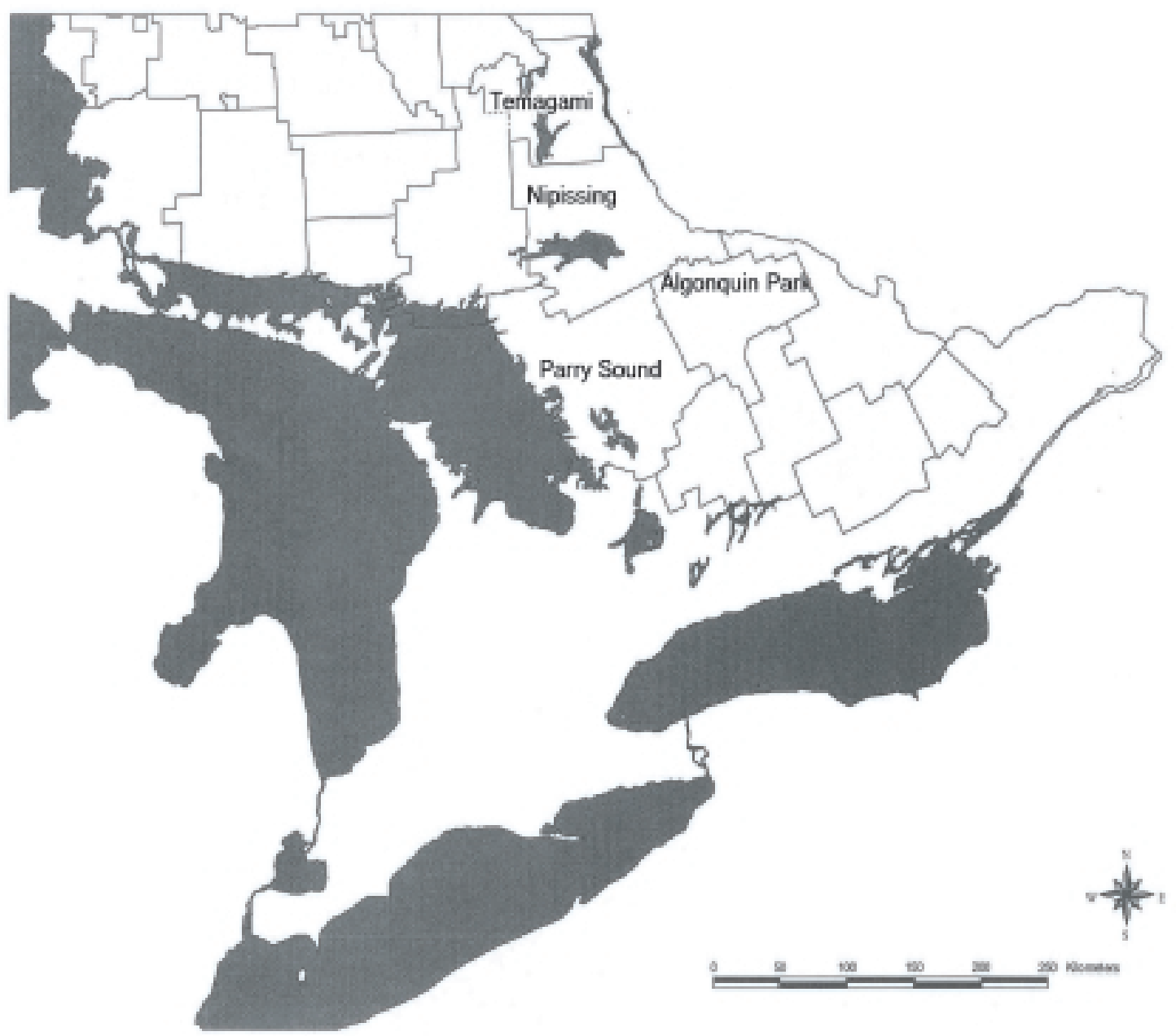

Fig. 1. Map of Ontario showing the four management units included in this study of historical forest cover. Note: Parry Sound is also called French-Severn.

this study will prove a useful tool showing how working group proportions of these forests have changed since 1890 and implications these changes may have on plant and animal habitats. Forest managers can use results found in this study to better monitor, understand and manage these ecosystems. Recommendations are also made regarding the implications and possible uses of results found from this study.

Numerous studies across the United States have used General Land Office survey records to reconstruct distribution, composition, successional status, and/or disturbance history of the presettlement forest (Bromely 1935, Nelson 1957, Weunscher and Valiunas 1967, Siccama 1971, Lorimer 1977, Whitney 1987, Palik and Pregitzer 1992, Schwartz 1994, Barrett et al. 1995, Deelen et al. 1996). In Canada, Clarke (1969), Pile (1969), Heidenreich (1973), Davis (1986), and Keddy (1993) all used Crown Survey records to estimate historic forest composition in various parts of southern Ontario. The only published study conducted in the Great Lakes-St. Lawrence forest of central Ontario used Crown Survey records to compare forest conditions in 1857 and the 1980s and 1990s along the north shore of Lake Huron (Jackson et al. 2000).

Few other sources of information exist for a reconstruction of Ontario's forests. Bromley (1935) discussed reconstruction techniques of forests and pointed out that land surveyor's records have been most commonly used. Bourdo (1956) stated that surveyor records possess the advantage of having been written in situ according to a pre-determined plan. Thus, they constitute an unbiased sample of vegetation communities and can be used for both quantitative as well as qualitative analysis (Bourdo 1956). Most recently, Schulte and Mlandenoff (2001) describe the uses and limitations of US public land survey records in reconstructing presettlement vegetation.

Because the Crown Surveys are considered a reasonably standardized method of sampling, Noss (1985) pointed out that survey records could be statistically compared with each other and to equivalent samples from modern vegetation. Thus, 
Table 1. A sample of the database spreadsheet prepared from circa 1890 Crown Survey notes

\begin{tabular}{|c|c|c|c|c|c|c|c|c|}
\hline $\begin{array}{l}\text { Township } \\
\text { Name }\end{array}$ & $\begin{array}{c}\text { Year } \\
\text { Surveyed }\end{array}$ & $\begin{array}{l}\text { Boundary } \\
(\mathrm{N}, \mathrm{S}, \mathrm{E}, \mathrm{W})\end{array}$ & $\begin{array}{l}\text { Length } \\
\text { (Chains) }\end{array}$ & $\begin{array}{l}\text { Land } \\
\text { Class }\end{array}$ & $\begin{array}{c}\text { Land } \\
\text { Class \# }\end{array}$ & $\begin{array}{l}\text { Working } \\
\text { Group }\end{array}$ & $\begin{array}{c}\text { Species } \\
\text { Composition }\end{array}$ & Comments \\
\hline Brewster & 1890 & North & 36 & Forest & 20 & PJ & PJ B PW & Burn \\
\hline Brewster & 1890 & North & 14 & Lake & 70 & & & Smith Lake \\
\hline Brewster & 1890 & North & 30 & Forest & 20 & PJ & PJ SB PO & \\
\hline Brewster & 1890 & North & 5.24 & Marsh & 52 & & & \\
\hline Brewster & 1890 & North & 43.3 & Forest & 20 & SB & SB L & Windfall \\
\hline Brewster & 1890 & North & 6.92 & Lake & 70 & & & \\
\hline Brewster & 1890 & North & 24.54 & Forest & 20 & SB & SB & \\
\hline Brewster & 1890 & North & 49 & Forest & 20 & SB & SB BW PO & Burn \\
\hline Brewster & 1890 & North & 2 & Rock & 56 & & & \\
\hline Brewster & 1890 & North & 24 & Forest & 20 & SB & SB L PO & \\
\hline Brewster & 1890 & North & 0.3 & River & 71 & & & \\
\hline Brewster & 1890 & North & 10 & Marsh & 52 & & & \\
\hline Brewster & 1890 & North & 58 & Forest & 20 & PJ & PJ & \\
\hline Brewster & 1890 & North & 17 & Forest & 20 & PJ & PJ PW BW & Burn \\
\hline Brewster & 1890 & North & 80 & Forest & 20 & SB & SB L PO & \\
\hline Brewster & 1890 & North & 34.1 & Forest & 20 & SB & SB L & \\
\hline Brewster & 1890 & North & 22.53 & Lake & 70 & & & \\
\hline Brewster & 1890 & North & 3.37 & Marsh & 52 & & & \\
\hline Brewster & 1890 & North & 15 & Bog & 50 & SB & SB AB & New burn \\
\hline Brewster & 1890 & North & 27 & Forest & 20 & PJ & PJ SB PO & \\
\hline Brewster & 1890 & North & 23 & Forest & 20 & PW & PW PR PO & \\
\hline
\end{tabular}

survey records are useful for identifying and mapping plant communities and species distributions, relating the vegetation to physical factors of the environment, comparing the presettlement condition to the present, managed one and providing guidelines for natural area inventory and management (Noss 1985).

\section{Methods}

The study was conducted on four forest management units (MUs) in central Ontario within the Great Lakes-St. Lawrence Forest Region. The Algonquin Park, French-Severn, Nipissing and Temagami MUs were selected because they represent a rough north-south transect, through the Great Lakes-St. Lawrence Forest (Fig. 1). The forests, physical geography and landscape ecology of Ontario has been discussed extensively in Perera et al. (2000) including this part of central Ontario.

The original Crown Survey records represent, in today's terms, the cruise notes of a particular survey line in a forested area. Surveyors would follow a pre-determined bearing through the forest marking township boundaries, road allowances, and lot corners. In addition, they recorded information on land type, landform, soil productivity, and forest cover. Detailed descriptions of forest cover included species (in order of abundance), the relative ages, health and diameter at breast height of the trees they encountered. This completed database represents the 1890 (circa) forest condition and is the basis of comparison to the present forest condition. In total, the 1890 database for this study consists of approximately 7000 kilometres of survey lines along township or concession boundaries.

Table 1 illustrates how the original surveyors' notes were summarized. The first three columns give basic information about which township was surveyed, in which year and the particular side of the township. The next four columns characterize the forest landscape. The length column reports the distance in chains of that land class. For example, row one is 36 chains in length, is a forest stand, land class number 20 and is composed of three species: jack pine (Pinus banksiana), balsam fir (Abies balsamea) and white pine (Pinus strobus). Since jack pine was listed first by the surveyor, it has been assumed that it is the dominant species or working group. A working group is the dominant species in a given forest stand. This assumption, which is based on survey instructions (Sebert 1980), has been made for the entire database. The comment column lists any other type of information noted by the surveyor; for example, row one was a burned area. Typically, the comment column includes information such as disturbances, lake names or any other data that could prove useful for land settlement.

One of the limitations of the survey notes was the identification of certain tree species. Depending on the year of the survey and the individual surveyor, certain species of trees were identified to the genus level but not to the species level, including spruce (Picea spp.), pine (Pinus spp.), birch (Betula spp.), and maple (Acer spp.). To compensate for this problem, species of these genera were grouped into general categories. The spruce group included black spruce (Picea mariana) and white spruce $(P$. glauca), the pine group included white pine and red pine $(P$. resinosa). The surveyors did identify jack pine and as such it was not included in the pine group. The maple group included soft (Acer rubrum) and hard maple (A. saccharum). The birches were not pooled because we believed they could be separated by their association with other species. Certain tree species were placed into "supergroups." For example, eastern white cedar (Thuja occidentalis) and larch (Larix laricina) were grouped as "other conifer" (OC) and beech (Fagus grandifolia), elm (Ulmus spp.), basswood (Tilia americana) and ironwood (Ostrya virginiana) as "other hardwoods" $(\mathrm{OH})$. Where the survey notes permitted, oaks (Quercus spp.) were grouped as a working group or placed in "other hardwoods."

The Ontario Forest Resources Inventory (FRI) provides a mapped and tabular inventory of the forest cover in the province for current conditions. It was developed from a combination of air photo interpretation and ground sampling. FRI maps show the location of lakes, rivers, wetlands, rock barrens, cultural features, and forest stand polygons. For each forest stand, the FRI contains information on stand age, height, species composition, site quality and density. FRI data from the early 
1990s were acquired for the same townships covered by the survey notes to provide a picture of the current forest composition. Data from the 1990s were used because they represented the most complete inventory at the time this project began and also permitted us to look at forest changes over approximately a 100-year time span. While it was possible to overlay survey lines on FRI maps, we decided to compare entire FRI township proportions to entire survey line proportions because the amount of work to overlay survey lines was prohibitive.

The majority of FRI data are gathered from air photo interpretation. This task is assigned to professional interpreters who distinguish different stands based on colours, textures and shapes found in the photo. Some interpreters tend to clump certain stands while others may separate the same stand into several stands. This clumping and separating may cause certain "rare" species that make up less than $10 \%$ of a stand disappear from the database. However, the FRI data represent the best available inventory of the forest and can be used as a valid estimate of the "present" forest cover condition.

One final limitation of this study is that there is a 100-year period between comparisons of which there is little mention. Incorporating data from 1950 would enhance this study, allowing us to check for global trends and support interpretation. Although the scope of this study was to compare 1890 to 1990 forest cover proportions, the use of 1950s data would be prudent in any subsequent studies.

\section{Analyses}

Forest cover data from 1890 and 1990 for all MUs were compared to determine if there were significant differences between the frequency of occurrence of selected species and differences between proportions of working groups. Working group proportions for 1890 were calculated by dividing the length of survey line associated with each working group by the total length of survey line. The 1990 working group proportions, taken from FRI data, were calculated by dividing the area of each working group by the total area.

The frequency of occurrence of species in the 1890 database was calculated by dividing the number of times a species was recorded along survey line segments by the total number of species entries along the entire length of survey lines. The survey notes and FRI databases represent the 1890 and 1990 forest cover conditions respectively. Examining the number of times a given species was documented provides a frequency of occurrence statistic. Frequency of occurrence represents a measure of the proportion of stands or survey line segments that contained a given species, but does not reflect absolute changes in relative abundance over the entire landbase.

From the 1990 database, frequency of occurrence of each species was calculated by dividing the number of times a species was recorded within all stands by the total number of entries of all species within all stands. Values were calculated for each of the townships within a management unit and then 1890 and 1990 databases were compared using a paired t-test (Snedecor and Cochran 1967).

These comparisons are not based on the actual amount of area or timber in a township, but rather the proportional representation of different species. Table 2 demonstrates this point effectively, from a sample of the data analyzed. In 1890, forest composition was described along 6013 chains of survey line, while in 1990, the FRI describes forest composition across
Table 2. A sample of the data taken from Crown Survey notes, circa 1890, and the 1990 data taken from Forest Resource Inventory data 1990

\begin{tabular}{lcrrr}
\hline & 1890 & 1890 & 1990 & 1990 \\
\hline Species & $\begin{array}{c}\text { Length } \\
\text { (Chains) }\end{array}$ & Percent & $\begin{array}{c}\text { Area } \\
\text { (ha) }\end{array}$ & Percent \\
\hline Bf & 234 & 3.89 & 3467 & 21.34 \\
Bw & 645 & 10.73 & 276 & 1.70 \\
By & 21 & 0.35 & 354 & 2.18 \\
He & 567 & 9.43 & 1456 & 8.96 \\
M & 1345 & 22.37 & 7534 & 46.36 \\
Oc & 34 & 0.57 & 65 & 0.40 \\
Oh & 197 & 3.28 & 35 & 0.22 \\
P & 598 & 9.95 & 876 & 5.39 \\
Pj & 798 & 13.27 & 275 & 1.69 \\
Po & 1098 & 18.26 & 1345 & 8.28 \\
S & 476 & 7.92 & 567 & 3.49 \\
Total & 6013 & 100.00 & 16250 & 100.00 \\
\hline
\end{tabular}

16250 ha of forest in the same township. The cogent comparison is between the proportion of each species in the forest, and not the area of land covered by forest.

\section{Results}

Table 3 summarizes all of the analyses for the four management units including the regional level. The bolded items refer to statistically significant $(\mathrm{P}<0.05)$ changes in the proportions of working groups, or frequency of occurrence. The working group analysis shows the changes found in stands that are dominated by a particular species, while the frequency of occurrence analysis shows the changes found in the amount of a particular species throughout the forest. Negative values represent a decrease in that species or grouping, while a positive value indicates an increase in that species or grouping. The percent changes in Table 3 represent change relative to the entire landbase, not the starting proportion of a working group or species, i.e., if a WG declined from $50 \%$ to $25 \%$, this is noted as a $25 \%$ decline $(=50-25)$, not a $50 \%$ decline $(=(50-25) / 50)$.

Maple showed the greatest change as both a working group and as a species. The proportion of the forested area dominated by the maple working group increased by $12.5 \%$ across the region. All MUs except Temagami showed significant increases ranging from 10.8 to $17.1 \%$. As a species, maple increased $7.2 \%$ at the regional level, with increases ranging from about $4 \%$ in Temagami and French-Severn to about $12 \%$ in Nipissing.

In contrast to maple, hemlock, balsam fir and the other conifer working group showed a broad decline over the region as a whole, with hemlock decreasing $2.3 \%$ as a working group and $3.1 \%$ as a species and balsam fir decreasing 3.5\% and $5.7 \%$ as a working group and a species respectively. The other conifers declined $2.06 \%$ as a working group (Table 3 ).

White birch has declined as a species but not as a working group in the region as a whole; however, there are some interesting exceptions. Temagami, for example, shows an increase in the proportion of the white birch working group, although as a species alone, there is no change. The poplar working group increased $5.8 \%$ as a species over the entire region, although most of the increase occurred in the French-Severn area.

\section{Discussion}

The reasons for an increase in the proportion of maple in this forest probably involves timber harvest techniques, fire suppression and the nature of shade-tolerant species. Historic 
Table 3. A comparison of changes in proportion of working groups and species occurrence in selected regions of Ontario between circa 1890 and 1990. Bolded items $=$ significant change $P<0.05,(-)=$ decrease, $(+)=$ increase, regular type $=$ no change

\begin{tabular}{|c|c|c|c|c|c|c|}
\hline Analysis & Species & $\begin{array}{l}\text { Regional } \\
\text { d.f. } 37\end{array}$ & $\begin{array}{c}\text { Algonquin Park } \\
\text { d.f. } 9\end{array}$ & $\begin{array}{c}\text { French-Severn } \\
\text { d.f. } 9\end{array}$ & $\begin{array}{l}\text { Nipissing } \\
\text { d.f } 9\end{array}$ & $\begin{array}{c}\text { Temagami } \\
\text { d.f. } 7\end{array}$ \\
\hline Working Group & A & 0.22 & N/A & -0.13 & 0.09 & 0.01 \\
\hline Working Group & $\mathrm{BF}$ & -3.47 & -2.55 & 0.12 & -12.40 & -6.01 \\
\hline Working Group & BW & 1.20 & -6.71 & -4.96 & 2.92 & 15.51 \\
\hline Working Group & BY & -0.18 & -0.07 & -0.77 & -0.68 & -4.96 \\
\hline Working Group & $\mathrm{CE}$ & N/A & N/A & N/A & N/A & -4.39 \\
\hline Working Group & $\mathrm{HE}$ & -2.33 & 2.21 & -11.55 & 0.50 & N/A \\
\hline Working Group & $\mathrm{L}$ & N/A & N/A & N/A & N/A & -1.10 \\
\hline Working Group & M & 12.48 & 16.70 & 17.11 & 10.81 & 4.16 \\
\hline Working Group & $\mathrm{O}$ & 0.48 & N/A & 1.41 & N/A & 0.13 \\
\hline Working Group & $\mathrm{OC}$ & -2.06 & -1.23 & -6.56 & -4.31 & N/A \\
\hline Working Group & $\mathrm{OH}$ & -1.24 & -3.73 & -2.05 & 0.14 & N/A \\
\hline Working Group & $\mathrm{P}$ & -2.98 & 0.71 & -1.69 & -0.93 & N/A \\
\hline Working Group & PJ & -5.59 & -0.75 & 0.11 & -4.20 & -10.34 \\
\hline Working Group & $\mathrm{PO}$ & 2.72 & -7.05 & 9.38 & 2.85 & 0.61 \\
\hline Working Group & PR & N/A & N/A & N/A & N/A & -5.54 \\
\hline Working Group & PW & N/A & N/A & N/A & N/A & 2.96 \\
\hline Working Group & $\mathrm{S}$ & 0.11 & 2.48 & -0.42 & 5.21 & 0.19 \\
\hline Occurrence & A & 0.89 & 0.24 & 2.22 & 1.01 & 0.07 \\
\hline Occurrence & $\mathrm{BF}$ & -5.77 & -3.36 & -7.93 & -5.43 & -6.38 \\
\hline Occurrence & BW & -3.95 & -11.79 & -9.73 & 0.96 & 4.64 \\
\hline Occurrence & BY & 3.83 & 7.34 & 2.55 & 5.09 & 0.29 \\
\hline Occurrence & $\mathrm{CE}$ & -1.18 & -2.43 & -1.18 & -3.25 & 2.14 \\
\hline Occurrence & $\mathrm{HE}$ & -3.14 & -1.31 & -11.24 & 0.003 & N/A \\
\hline Occurrence & $\mathrm{L}$ & -1.59 & -0.69 & -0.10 & -4.62 & -0.92 \\
\hline Occurrence & M & 7.23 & 9.42 & 3.97 & 11.95 & 3.56 \\
\hline Occurrence & $\mathrm{O}$ & 1.25 & 1.20 & 2.82 & N/A & 0.17 \\
\hline Occurrence & $\mathrm{OC}$ & N/A & N/A & N/A & N/A & N/A \\
\hline Occurrence & $\mathrm{OH}$ & -6.24 & -4.97 & -8.65 & 0.81 & N/A \\
\hline Occurrence & $\mathrm{P}$ & 0.91 & -1.75 & 9.11 & -11.33 & N/A \\
\hline Occurrence & PJ & -0.91 & -1.28 & 2.28 & -1.77 & -2.84 \\
\hline Occurrence & $\mathrm{PO}$ & 5.83 & 4.09 & 12.35 & 7.96 & -1.08 \\
\hline Occurrence & PR & N/A & N/A & N/A & N/A & -4.65 \\
\hline Occurrence & PW & N/A & N/A & N/A & N/A & 0.51 \\
\hline Occurrence & $\mathrm{S}$ & 2.84 & 5.14 & 3.52 & -1.81 & 4.47 \\
\hline
\end{tabular}

removal of other commercially important species during the last century, such as pine, oak or yellow birch, likely provided the ideal conditions for maple to flourish. The increase in maple-dominated forest has likely been at the expense of hemlock, yellow birch, other hardwood and pine dominated forest proportions, although only hemlock is statistically significant (Table 3).

Selective logging of pine, oak and yellow birch not only removes those species, but creates conditions that mimic the natural process of gap phase replacement. This process tends to favour trees that are either represented by saplings or as seedlings ready to take advantage of the new conditions. Maples are prolific seed-producers and seedlings can remain in the understory for years waiting for a space to open in the canopy. Forest practices that selectively remove trees from the forest in this part of Ontario tend to perpetuate maple working groups (Burns and Honkala 1990). During most of the $19^{\text {th }}$ century, and the first half of the $20^{\text {th }}$ century, high-grading or selective logging occurred in these management units and the residual canopy in these areas probably supported growth of maple (Carleton 2000).

Fire suppression efforts began around 1920 in central Ontario and really became effective after 1950 (Ward and Tithecott 1993). This appears to have permitted long-lived tolerant species such as maple to gradually dominate forest types on drier sites that would historically have been dominated by fire-adapted species such as red oak and that would have been perpetuated by frequent fires (Dey and Parker 1996, Carleton 2000).

The other conifer working group (cedar and larch), as a percentage of the forest, has dropped to almost half of its presettlement level. Howse (1983) pointed out that larch was almost eradicated in the late 1800 s and early 1900 s by the larch sawfly (Pristiphora erichsonii). Both larch and cedar were used extensively by settlers in this region in construction of farms, and this too, may have contributed to a lower proportion of these species (Macfie 1987). High deer numbers that existed throughout most of the 1900s, which would have an impact on cedar regeneration, may also explain the decrease in cedar.

The decrease in hemlock, to almost a quarter of presettlement proportions over the region as a whole, may be due largely to heavy harvesting of this species in the mid 1900s for railway ties, subway timbers for Toronto and hemlock bark which was used in the tanning process (Macfie 1987, Kershaw and Gordon 1991). Selective removal of hemlock in mixed stands likely leads to replacement by maple. Moreover, hemlock is a preferred winter browse of deer and effects of heavy harvest were likely exacerbated by suppression of hemlock regeneration by high deer numbers in the early and mid 1900s (Anderson 1990).

According to Kershaw and Gordon (1991), the period of 1870 to the 1950s was an intense harvesting period of hemlock in 
this region. Kershaw and Gordon (1991) also point out that there is still a slow decline in the proportions of hemlock because it is often removed along shorelines for cottage development and regeneration is often heavily browsed by ungulates. They also explained that some of the hemlock in Algonquin Park was, and still is, inaccessible to harvesting, which might explain why hemlock levels have remained relatively stable in the park.

The data from about 1890 to 1990 show little significant change in pine frequency over the region, with the exception of red pine in Temagami. This has probably occurred because almost all of the exploitation of pine for building material and ship's masts was finished by the 1880s in this area (MacKay 1978). The first wave of pine exploitation preceded the land surveyors - thus estimates from the late 1800s may not be reflective of the amount of pine forest in these townships prior to European arrival. Red pine in Temagami, however, was the exception because it has declined during this period.

For some species, the frequency of occurrence has significantly changed since 1890 , yet their corresponding working group analysis has remained unchanged. The working group levels of ash have been historically low and have remained unchanged, yet the frequency of occurrence of ash has increased slightly. Ash, typically black ash in this region, grows in wet sites with soft maple, balsam fir and black spruce (Farrar 1995). These sites are wet, often do not contain much merchantable volume, and are rarely harvested, which may explain why the working group has remained unchanged. The small increase in ash frequency of occurrence probably occurred on drier sites where, for reasons that are not clear, ash regeneration was favoured.

The working group analysis for yellow birch shows that no significant changes occurred except in Temagami. This may mean that like maple, yellow birch is found more often in other working groups in the 1990s, than it was in 1890. However, unlike maple, yellow birch working groups have remained relatively stable. It is unclear as to why yellow birch working groups have remained unchanged yet frequency of occurrence proportions has increased. However it is possible that yellow birch is increasing in previously heavily harvested hemlock stands.

The increase in spruce may be due to the decrease in balsam fir because of the spruce budworm outbreak. Balsam fir proportions are down significantly, both in working groups and frequency of occurrence. The increase in spruce frequency of occurrence may be attributed to the idea that working groups of spruce would be easier to colonize than scattered occurrences. This would suggest that there has been enough time for residual occurrences of spruce to recover and increase since budworm invasions. Alternatively, another possibility is the fact that when balsam fir was removed from spruce-fir forests by the budworm, only spruce remained and thus its relative frequency of occurrence increased.

White birch grows on a wide variety of soils and is among the first species to colonize after a fire or cutting (Hosie 1990). Fire suppression efforts have become more effective since about the 1950s and Thompson (2000) and Li (2000) illustrate some of the major consequences of fire management and other factors that influence vegetation in central Ontario. The lower frequency of occurrence levels of white birch suggests that fire suppression efforts throughout the region may have caused lower proportions of this species in forested areas. However, in Temagami, white birch working group proportions have increased substantially, while regional levels have not changed.
Government records show that Temagami experienced several very large and hot fires since the 1920s (Ward and Tithecott 1993). These fires may have caused levels of white birch to increase in Temagami while not in other management units.

Occurrences of the other hardwood grouping have decreased since 1890, while the working group proportions have not changed. These species are generally mid-tolerant species and the widespread use of selection management that tends to favour tolerant species such as maple may have caused other hardwood species to decline in proportion on the landscape. Some of these other hardwoods, which included oak among others, were highly desirable species and were selectively harvested in the past. Fire suppression may also be favouring replacement of mid-tolerant fire-adapted species such as oak by maple.

\section{Ecological Implications of Changes In forest Cover}

In the maple working groups, not only have significant increases occurred in three of the four management units as well as at the regional level, but also significant increases in the frequency of occurrence of maple as a species has occurred throughout the forest. The increase of maple in this forest region may be the most important finding of this study. This concept is very important to consider, as these changes not only affect working group proportions, but they also affect the proportions of frequency of occurrence in the forested landscape.

Certain species, such as Red-shouldered Hawks (Buteo lineatus), that prefer hardwood forests may have experienced increases in their habitat supply as a result of these changes. The Ontario Forest Bird Monitoring Program (2001) lists the most common species encountered by surveys in the summer of 2000 as: Red-eyed Vireo (Vireo olivaceus), Ovenbird (Seiurus aurocapillus), Great Crested Flycatcher (Myiarchus crinitus), Eastern Wood Pewee (Contopus virens), Blackcapped Chickadee, (Parus atricapillus), Veery (Catharus fuscescens), Wood Thrush (Hylocichla mustelina), Rosebreasted Grosbeak (Pheucticus ludovicianus), Scarlet Tanager (Piranga rubra) and Black-throated Green Warbler (Dendroica virens). All of these species use upland hardwood deciduous forest as breeding or foraging habitat and may have benefited from a gradual shift in maple in these forests.

However, populations of other softwood-dependent species, e.g., Red-breasted nuthatch (Sitta canadensis), Rudy-crowned Kinglet (Regulus calendula), Cape May Warbler (D. tigrina) and Blackburnian Warbler (D. fusca) may have less breeding habitat which could contribute to a decline in populations because of the significant increase in hardwoods in the region. The increase in hardwoods and declines in softwoods also means that there are fewer conifers in the forest and this could have detrimental effects for species such as white-tailed deer (Odocoileus virginianus) and moose (Alces alces) that rely on softwoods such as hemlock for food and winter shelter. While habitat is just one factor in the increase or decrease of wildlife populations, it is one of the most important variables in population fluctuations. Prudent managers and conservationists will need to monitor changes and impacts on wildlife in the region and consider the change in habitat as population monitoring continues.

The forest cover composition has changed significantly over the last century and this likely has affected several types of wildlife in the region. The problem this presents for man- 
agers is how to judge the change. An attitude that describes all change in diversity of the forest as unacceptable seems inappropriate. Yet, at the same time, if the changes identified here signal that forest management is proceeding towards a significant, fundamental alteration of the forests than were present before large-scale industrial management started, perhaps there is cause for concern.

\section{Recommendations}

The Crown Forest Sustainability Act (RSO 1994) has committed Ontario to an ecosystem approach to forest management. The CFSA requires that forests be managed in a way that emulates the patterns and processes perpetuated by natural disturbances. Furthermore, the Forest Management Planning Manual (OMNR 1996) directs managers to maintain forest composition and structure within the bounds of natural variability. Thus, there is clear direction to managers to attempt to reverse some of the changes noted by this study and by Jackson et al. (2000) that have occurred in the forests of central Ontario during the last 100 to 150 years.

Clearly, reducing the amount of maple forest and increasing the amount of hemlock and mid-tolerant hardwood forest will be a daunting challenge. It is likely not reasonable to expect that it will be economically feasible or socially desirable to restore these forest types to presettlement levels. While presettlement levels may not be reasonable management goals, they still can provide a benchmark by which to judge ecosystem health (Wimberly et al. 2000). Moreover, there are numerous positive steps that can be taken by managers to move the forests of central Ontario closer to the presettlement condition.

As a minimum, managers should strive for no net loss of forest types that are substantially reduced relative to the presettlement condition. Much of this goal can be achieved by applying intensive silvicultural practices (OMNR 1998a, b). For example, hemlock forest should be actively managed with shelterwood or group selection harvests followed by light site preparation to establish regeneration (OMNR 1998b); management should be conducted primarily in areas or during time periods with low deer numbers (Anderson 1990). Tending (manual or prescribed fire) should be conducted in oak forest on good sites to ensure oak regeneration is not swamped by maple regeneration (Dey and Parker 1996, OMNR 1998a). Yellow birch forest should be managed with shelterwood or group selection silvicultural systems; removal cuts in shelterwood-cut forest must be conducted in a timely manner to ensure release of yellow birch regeneration (OMNR 1998a).

Whenever feasible, sugar maple-intolerant hardwood stands on poor sites should be clearcut and converted to mid-tolerant conifer species. In most cases this will involve heavy mechanical site preparation, planting, and chemical tending (see OMNR 1998a, b). In maple-dominated forest on good sites, silvicultural practices should be modified to maintain other associated species that have declined. Maple stands with a significant component of mid-tolerant hardwoods should be managed with shelterwood or group selection silvicultural systems (OMNR 1998a). Single tree selection management of maple stands with a minor component of mid-tolerant hardwoods should include some group selection openings. Tree marking should always maintain minimum numbers of mast-producing trees (oak, beech, black cherry, basswood, ironwood) and scattered conifers (predominantly hemlock) as prescribed by
Naylor (1998). Moreover, when selecting among trees of equal quality, less common species should be favoured (OMNR 2001).

Some of the silvicultural practices needed to move the current forest toward the presettlement condition may not be aesthetically pleasing (e.g., removal cut in a yellow birch stand looks like a clearcut) and the general public may perceive them as not environmentally friendly. Forest managers will be challenged to reassure the public that disturbance is a natural ecosystem process and that severe disturbance is often required to maintain ecological integrity (Kimmins 1999).

If the major goal of modern forestry is to consider and conserve biodiversity then we must continue to monitor the relative abundances of the different communities to ensure healthy forests ecosystems (RSO 1994). By expanding these baseline historical surveys to include as much of the province as possible, a clearer picture of presettlement conditions will provide a goal for forest management to strive towards. The new century could be a time for Canadian forest management planners to lead the way to a sustainable ecological and economic future so that we may leave a diverse and healthy forest landscape for future generations.

\section{References}

Anderson, H.W. 1990. Hemlock: its ecology and management. In B. Naylor and L. Thompson (eds.). Regenerating Conifer Cover in Deer Yards. pp. 62-86. OMNR Central Ontario Forest Technology Development Unit Rpt. No. 28.

Barrett, L., J. Liebens, G. Brown, R. Schaetzl, P. Zuwerink, T. Cate, and D. Nolan. 1995. Relationships between soils and presettlement forests in Baraga County, Michigan, Amer. Midl. Nat. 134: 264-285. Bourdo, E. 1956. A review of the general land office survey and of its use in quantitative studies of former forests. Ecology 37: 754-768. Bromley, S. 1935. The original forest types of Southern New England. Ecological Monographs. 5: 61-89.

Burns, R.M. and B.H. Honkala. 1990. Silvics of North America, 2 vols. USDA Forest Service, Agriculture Handbook 654. Washington, D.C.

Carleton, T.J. 2000. Vegetation responses to the managed forest landscape of central and northern Ontario. In A. Perera, D. Euler and I.D. Thompson (eds.). Ecology of a Managed Terrestrial Landscape: patterns and processes of forest landscapes in Ontario. pp. 178-197. University of British Columbia Press, Vancouver, BC. 336 p.

Clarke, M.F. 1969. The general composition of the forest of North Dumfries Township, Waterloo County, Ontario, 1871. Unpublished BA Thesis, University of Waterloo, Waterloo, ON.

Davis, L. 1986. Evolving landscape productivities in four rural townships of Southern Ontario 1810-1980. Unpublished Ph.D. Thesis, University of Waterloo, Waterloo, ON.

Deelen, T., K. Pregitzer and J. Haulfer, 1996. A comparison of presettlement and present-day forests in two northern Michigan Deer Yards. Amer. Midl. Nat. 135: 181-194.

Dey, D.C. and W.C. Parker. 1996. Regeneration of red oak (Quercus rubra) using shelterwood systems. Queen's Printer for Ontario, Toronto, ON.

Farrar, J. 1995. Trees In Canada. Fitzhenry \& Whiteside Ltd., Markham, ON and the Canadian Forest Service, Ottawa, ON. 502 p.

Heidenreich, C. 1973. A procedure for mapping the vegetation of Northern Simcoe County from Ontario Land Surveys. Cartographica Monograph 8: 105-113.

Hosie, R.C. 1990. Native Trees of Canada, Fitzhenry \& Whiteside Ltd., Markham, ON and the Canadian Forest Service, Ottawa, ON. 380 p. Howse, G. 1983. Pests of Larch: Biology, Damage and Control, Department of the Environment, Canadian Forest Service, Sault Ste. Marie, ON. 
Jackson, S.M., F. Pinto, J.R. Malcolm, and E.R. Wilson. 2000. A Comparison of Pre-European Settlement (1857) and Current (1981-1995) Forest Composition in Central Ontario. Can. J. For. Res. 30: 605-612.

Keddy, C. 1993. Forest History of Eastern Ontario, Eastern Ontario Forest Group, Kemptville, ON.

Kershaw, H. and A. Gordon, 1991. Analysis of the status of Eastern Hemlock and its requirements, Central Ontario Forest Technology Development Unit.

Kimmins, J.P. 1999. Biodiversity, beauty and the "beast": are beautiful forests sustainable, are sustainable forests beautiful, and is "small" always ecologically desirable? For. Chron. 75: 955-960.

Li, C. 2000. Vegetation responses to the managed forest landscape of central and northern Ontario. In A. Perera, D. Euler and I.D. Thompson (eds.). Ecology of a Managed Terrestrial Landscape: patterns and processes of forest landscapes in Ontario. pp. 115-140. University of British Columbia Press, Vancouver, BC. 336 p.

Lorimer, C. 1977. The presettlement forest and natural disturbance cycle of Northeastern Maine, Ecology 58: 139-148.

Macfie, J. 1987. Parry Sound Logging Days. The Boston Mills Press, Erin, ON. 207 p.

MacKay, D. 1978. The Lumberjacks. McGraw-Hill Ryerson, Limited. Toronto, ON. 319 p.

Naylor, B.J. 1998. Habitat management considerations. In A Silvicultural Guide for the Tolerant Hardwood Forest in Ontario, Queen's Printer for Ontario, Toronto, ON.

Nelson, T. 1957. The original forests of the Georgia Piedmont, Ecology 38: 390-397.

Noss, R. 1985. On Characterizing Presettlement Vegetation: How And Why, Natural Areas Journal. 5: 5-19.

OMNR. 1996. Forest management planning manual for Ontario's crown forests. Queen's Printer for Ontario, Toronto, ON.

OMNR. 1998a. A Silvilcultural guide for the Tolerant hardwood Forest in Ontario. Queens Printer for Ontario, Toronto, ON.

OMNR. 1998b. A Silvilcultural Guide for the Great Lakes-St. Lawrence Conifer Forest in Ontario, Queen's Printer for Ontario, Toronto, ON.

OMNR. 2001. Ontario tree marking guide (draft). Queen's Printer for Ontario, Toronto, ON. 231 p.

Ontario Forest Bird Monitoring Program. 2001. Newsletter, Volume 11, Number 1, Spring 2001.
Palik, B. and K. Pregitzer. 1992. A comparison of presettlement and present-day forests on two bigtooth aspen-dominated landscapes in Northern Lower Michigan, Amer. Midl. Nat. 127: 327-338.

Perera. A.J., D.L. Euler and I.D. Thompson (eds.). 2000. Ecology of a Managed Terrestrial Landscape: Patterns and Processes of Forest Landscapes in Ontario. UBC Press, Vancouver, BC and the Ontario Ministry of Natural Resources, Toronto, ON. 336 p.

Pile, D. 1969. Methods of Analysing Original Vegetation Using Early Land Survey Records. Unpublished MA. Thesis, McMaster University, Hamilton, ON.

Schwartz, M. 1994. Natural distribution and abundance of forest species and communities in Northern Florida. Ecology, Vol. 75: 687-705.

Sebert, L.M. 1980. The Land Surveys of Ontario 1750-1980. Cartographica 17: 65-106.

Siccama, T. 1971. Presettlement and present forest vegetation in Northern Vermont with special reference to Chittenden County. Amer. Midl. Nat. 85: 153-172.

Schulte, L and D. Mladenoff. 2001. The Original US Public Land Survey Records: Their Use and Limitations in Reconstructing Presettlement Vegetation, J. For. 99(10): 5-10.

Snedecor, G.W. and Cochran, W. 1967. Statistical Methods (6 $6^{\text {th }}$ Edition). Iowa State University Press, Anes, Iowa. 593 p.

Statues of Ontario. 1994. Crown Forest Sustainability Act. S.O., c. 25 .

Thompson, I.D. 2000. Vegetation responses to the managed forest landscape of central and northern Ontario. In A. Perera, D. Euler and I.D. Thompson (eds.). Ecology of a Managed Terrestrial Landscape: patterns and processes of forest landscapes in Ontario. pp. 30-53. University of British Columbia Press, Vancouver, BC. 336 p.

Whitney, G. 1987. An Ecological History of The Great Lakes Forest of Michigan, J. Ecol. 75: 667-684.

Ward, P.D. and A.G. Tithecott. 1993. The impact of fire management on the boreal landscape of Ontario. Publication No. 305, Aviation, Flood and Fire Management, OMNR, Sault Ste. Marie, ON.

Wimberly, M.C., T.A. Spies, C.J. Long and C. Whitlock. 2000. Simulating historical variability in the amount of old forests in the Oregon coast range. Conserv. Biol. 14: 167-180.

Wuenscher, J. and Valiunas, A. 1967. Presettlement forest composition of the River Hills Region of Missouri, Amer. Midl. Nat. 78: 487-495. 